\title{
BUDGET DELIBERATION AS COMMUNICATIVE PRACTICE: THE CASE OF A RURAL MUNICIPALITY IN THE PHILIPPINES
}

\author{
Louise Antonette S. Villanueva* \\ Department of Development Broadcasting and Telecommunication, \\ College of Development Communication, University of the Philippine \\ Los Baños, Los Baños, Laguna, Philippines \\ E-mail: 1svillanueva@up.edu.ph
}

Published online: 30 July 2021

To cite this article: Villanueva, L. A. S. 2021. Budget deliberation as communicative practice: The case of a rural municipality in the Philippines. International Journal of Asia Pacific Studies 17 (2): 283-319. https://doi.org/10.21315/ijaps2021.17.2.11

To link to this article: https://doi.org/10.21315/ijaps2021.17.2.11

\begin{abstract}
This study explores how municipal council members communicate with each other during budget deliberations, and suggests ways in how they ought to communicate more effectively with each other. Guided by Grounded Practical Theory, the researcher has analysed the transcribed talks of the budget deliberations of a rural municipality in the Philippines from 2013 to 2016. Specifically, the researcher delves into three levels of budget deliberation as a communicative practice: (1) problem level or the dilemma that the municipal council members are presented within the conduct of the budget deliberations, (2) technical level or the "discourse moves" or strategies employed by the municipal council members to manage the dilemma and (3) philosophical level, which starts with "situated ideals" or the municipal council members' belief as to how they "ought" to act in the communicative practice. Through the analysis of transcribed talks and semistructured interviews, the researcher has identified three problems that municipal council members encounter during budget deliberations: (1) technicalities of the budget process and documents, (2) lack of information and (3) politics. To address these problems, municipal council members employ communicative strategies that could facilitate comprehension and/or consensus, stall, or fast-track the budget deliberation, namely: (1) code switch, (2) referral and deferral, (3) establishment of openness, assertion of competence, and making a plea, (4) clarification and
\end{abstract}


suggestion, (5) repetition, (6) show of empathy for constituents, (7) sarcasm, (8) redirection and restriction, (9) silence and (10) termination. Except for sarcasm and silence, these communicative strategies are also used to achieve the situated ideal of duty-centered budget deliberation that places importance on respect and continuous dialogue. The reconstruction of budget deliberation as a communicative practice shows that despite communicative problems, the municipal council members employ communicative strategies to help them accomplish their duties. The results also allow for the reflection on improvements to the budget deliberations and its implications on governance.

Keywords: communicative practice, grounded practical theory, local government unit, budget deliberation, governance

\section{INTRODUCTION}

The budget process is one of the most critical practices that governments conduct annually. In the Philippines, it involves all branches of the national government and all departments in local government units (LGUs). Due to its multi-level and multi-dimensional nature, setbacks and bottlenecks are common. The national budget relies on executive-legislative relations and this results in budget allocation problems stemming from rampant corruption and the lack of fiscal discipline and tax compliance (Blondal 2010: 3). The scarcity of monetary resources is not limited to the national government. At the local government level, the primary source of the budget is the Internal Revenue Allotment (IRA). However, the Asian Development Bank (2013: 3) reported unreliable IRA transfers to the LGUs. Up to $45 \%$ of the budget could be allotted to personnel services (Department of Budget and Management 2011: 3). The rest is what remains for social and economic services and other expenditures. The allocation is determined through the long process of deliberation among elected members of the municipal council.

Given the uncertainty surrounding the quarterly IRA releases and limitations in the local government budget, municipal council members must prioritise the services that will receive a share of the budget, and in turn, also decide what the government will and will not do. This shows the nature of budgeting as a political process wherein powers in structure, norms, and values are evident (Norton and Elson 2002). Budget actors such as municipal council members are expected to exercise their power to advance their budgetary goals (Rubin 2014) and use strategies to control, 
manage, plan, and approve funding of certain programmes (Stanford 1992). This could lead to discomfort, tension, or conflict during budget deliberation. These discomforts, tensions, or conflicts are deemed by Tracy (1995) as interesting moments because they can provide an in-depth understanding of communicative problems, strategies, and situated ideals as municipal council members interact among themselves.

The budget process is a common topic of interest among scholars. Aside from looking at the process using the political science perspective, many studies often analysed budgeting through the lens of accounting, management, and economics (e.g., Leach-López et al. 2007; Kyj and Parker 2008; Venkatesh and Blaskovich 2012). This article, on the other hand, considers the budget process, particularly the budget deliberation at the local government level as a communicative practice. Through the use of Craig and Tracy's (1995) Grounded Practical Theory (GPT), this article addresses two research questions: "How did municipal council members communicate during budget deliberations?" and "How do municipal council members ought to communicate during budget deliberations?" Specifically, this article aims to examine the following: (1) the communicative problems encountered during budget deliberations, (2) the communicative strategies employed by the municipal council members to address such problems and (3) the situated ideal that guides how municipal council members communicate during budget deliberations.

This article describes the budget deliberations and paves the way for future scholars to consider how budget deliberation can be a form of communicative practice. As this article shows, the municipal council members recognised how they communicated, and they also thought about why they communicated a certain way and how they should have communicated during budget deliberations. In this regard, the article provides both description and critique of municipal budget deliberations wherein communication plays a key role in determining programmes and services to be provided to constituents. It should be noted that the data analysed in this article comes from just one municipality in the south of Manila. Hence, the results are not generalisable or applicable to other municipalities in the Philippines. 


\section{LITERATURE REVIEW}

\section{Characteristics and Importance of Deliberation}

Deliberative democrats who have deviated from the theory and practice of classical democracy consider deliberation as an essential and nonnegotiable democratic process. Dryzek and Niemeyer (2012: para. 8) define deliberation as a process that "involves multidirectional conversation aimed at improving both understanding and decision-making". Dryzek and Pickering (2017) also view deliberation as a driver of reflexivity because of its capacity to manage tensions between the following dichotomies: (1) participation and expertise, (2) diversity and consensus, (3) polycentricity and centralisation, and (4) flexibility and stability.

Among the key characteristics of deliberation are the inclusion and participation of concerned parties as well as the rationality of communication using persuasive arguments (Tracy and Hughes 2014). At its best, it is characterised as follows: (1) access to information of the parties, (2) substantive balance where there is an adequate exchange of reasons and arguments among parties, (3) diversity through the representation of various opinions by several parties, (4) conscientiousness or honest assessment of arguments based on merits and (5) equal consideration, which means that the merits of reasons and arguments are given more weight regardless of its source (Fishkin 2009: ch. 6). Deliberation is also seen as an exhibition of equality and political conversation (Dutwin 2003).

Likewise, deliberation is not just a discussion. It encourages the participation of marginalised groups, tempers elitism and creates a space for pluralism through mutual recognition of differences. It also has procedural and dispositional components. The latter allows actors to take a "deliberative stance", wherein they consider exchanging reasons with fellow actors to reach a common judgment (Curato et al. 2017). Empirical tests have proven these claims. Deliberation is deemed different from other discussions and decisionmaking processes, especially in position formation. With adequate reasongiving and inclusivity, deliberation leads to more knowledge gains for actors that can change their positions on issues (Schneiderhan and Khan 2008). Incorporating deliberation on policies could also result in recognition of important human values and awareness of one's actions (Kenter et al. 2011). 


\section{Deliberation in Practice: Problems and Strategies}

Since deliberations involve individuals and groups of varying interests, it is common for problems to arise in the process. Foremost is the use of force instead of reasons in evaluating the merits of arguments (Cohen 1989: 22-23). Force is integral to the existence of judgmental constraints, which prevent actors from reflecting on how they should vote and why they should vote in favour of one argument over another. Parties might also experience dialogical constraints, especially if they stick to their personal opinions instead of forming or changing these opinions through constant dialogue with others. Furthermore, it is common for deliberations to have inclusive constraints wherein parties are not directly represented (Pettit 2003: 139).

In addition to the aforementioned constraints, there are deliberation barriers that prevent the improvement of government functions such as policymaking. These barriers are as follows: (1) power needs, (2) political irrationality versus technical rigidity, (3) different perspectives, (4) parttime versus full-time employees, (4) technical experts versus citizens, (5) public apathy and feelings of powerlessness, and (6) public proceedings (Municipal Research and Services Center of Washington 1999: 25-26). Some of these barriers are also noted in the findings of Wooley and Gardner (2017). Their study of the Federal Open Market Committee suggests that leaders and their capacity to facilitate and ensure equality among parties are imperative to deliberative reasoning. The same is articulated about the expression of dissent.

Problems are ever-present in deliberations, and parties employ strategies that will address these problems and help them achieve their desired outcomes such as understanding, agreement, consensus, or even dissent. These strategies and their determinants have been the subject of research studies.

In their research about online deliberations on food safety, scholars from the Ghent University have found that cognitive, attitudinal, and/or behavioural functions determine actors' activities during deliberations. These activities also increase through the use of interactive media (Rutsaert et al. 2015: 197-198). However, it has been argued that while online deliberations can be exercised with fewer barriers, interaction guidelines should be implemented (Mummery and Rodan 2013: 36-37).

Another common communicative strategy in deliberation is storytelling. Personal anecdotes in deliberation serve as a mechanism for actors to share information, and at the same, make the opposing 
parties realise the similarities and differences in their experiences (Black 2009, cited in Myers and Mendelberg 2013: 16; Walsh 2007, cited in Myers and Mendelberg 2013: 16). Actors in deliberation also use modes that encourage and permit disagreements over social conversations (Polletta 2008, cited in Myers and Mendelberg 2013: 16). For others, employing a decision-oriented deliberation is important to arrive at a collaborative solution geared towards addressing problems (Van de Ven et al. 2017: 1335).

Message or information is also a key consideration. While information relevance and sufficiency do not affect an actors' deliberative activity, the perceived complexity of information is a deterrent to deliberation. Accordingly, actors would prefer to avoid deliberation than risk their reputation. Information could also be leveraged to achieve an actor's desired outcomes in deliberation, especially if he or she is an expert whose actions can indicate knowledge of hidden information (Jacson and Tan 2013: 23).

More than orientations, channels, and messages, the importance of feedback as a communicative strategy has also been recognised. For Gutmann and Thompson's (2004: 3-4), feedback through reason-giving and accessibility to reasons are key to successful deliberation because they ensure the continuity of exchanges. Jacson and Tan $(2013,23)$ report that through feedback, an expert's values can be aligned with his or her audience during deliberations. Kenter et al. (2016: 288) have also found that shared values are established during deliberations because these permit active reflection on outcomes.

Another vital component of deliberation is participation. Ojha et al. (2009: 373) have argued that deliberations could also be used to perpetuate a political order. Thus, deliberation can become a barrier to participation. Given such possibilities, the scholars also note that the actors have employed different strategies to address these problems. In a scoping study of public deliberation in public health issues and policies, the preferred technique is "citizen's jury", wherein ordinary citizens are the primary sources of decisions on the premise that they can craft informed decisions based on complicated and sometimes contested scientific data (Degeling et al. 2016: 117). The struggles are also evident in deliberations for the governmental budget. Holdo (2016) argues that inclusion to deliberation should move past the requisites of deliberative skills or capacities. Instead, deliberative capital based on norms should be recognised as the basis of the actor's legitimacy. This can provide better grounding for the deliberation 
as it considers the interpretation of actual citizens or end audience. The focus on citizen's participation in budget deliberation is preferred because it has resulted in a more focused and prioritised expenditure (Gonçalves 2014). Similar findings have been reported by Walker (2016). Aside from active participation in all the stages of participatory budgeting, joint planning and joint fact-finding have also been found to be crucial to the success and the mitigation of conflict in the initiative.

\section{Ideals of Deliberation}

In discussing the ideals of deliberation, scholars often refer to the work of Jurgen Habermas, who has delved into the concept of argumentation in modern societies (1981, as cited in White 1988: 56). He has reiterated that for participants to come up with consensus solely based on the merits of arguments, they must take part in what he deems as the "ideal speech situation". This can only be achieved through the observation of the following rules:

1. Each subject who is capable of speech and action is allowed to participate in discourses.

2. a. Each subject is allowed to call into question any proposal.

b. Each subject is allowed to introduce any proposal into the discourse.

c. Each subject is allowed to express his attitudes, wishes and needs.

3. No speaker ought to be hindered by compulsion - whether arising from inside the discourse or outside of it - from making use of the rights secured under (1) and (2).

Habermas' ideal speech situation is characterised by the principles of mutual understanding, truthfulness, sincerity, right to speak and social order (Ritzer 2011: 290-293). While many scholars recognise the ideals forwarded by Habermas, refinements have also been offered. Mezirow (1985: 144) emphasises the rules by stating that participants should be equipped with complete information, argumentative skills and self-knowledge. Day (1993: 9) also expounds on the suggestions of Bredo and Feinburg of Temple University, who state that an ideal speech communication must not have violence. Instead, it must have wide boundaries for "public" and "private" speech, the capacity to challenge traditions and rules of speech, 
and equal opportunity. Habermas (2008, as cited in Gillespie et al. 2014: 73) himself revised the ideals by emphasising that dialogues in these situations must observe the principles of inclusiveness, equal right, lack of deception and absence of coercion.

The ideals set by Habermas are common in other normative theories of deliberation. In the extensive review of the literature, Myers and Mendelberg (2013) note that several scholars have also forwarded the ideals of equality, open-mindedness and freedom of speech in deliberations regardless of the participants' backgrounds. While their discursive strategies varied, deliberative democrats and scholars have agreed that understanding should be evident among participants. However, there are contentions in terms of desired outcomes. For scholars like Cohen (1989), voting should be done to legitimise decisions, while Gutmann and Thompson (1996, as cited in Myers and Mendelberg 2013: 2) emphasise mutual understanding as the outcome of deliberation. These are countered in the study conducted by Scudder (2016), which favours differences over consensus. Accordingly, differences instead of empathy can sustain deliberative practices and hone skills necessary for deliberation among participants.

Aside from mutual understanding, scholars have focused on other outcomes expected from ideal deliberation. Among them are Dryzek and Niemeyer (2012: para. 7), who point out that deliberation can result in satisfaction and "a good deal of change to the positions of individuals". However, the meta-research conducted by Myers and Mendelberg (2013: 19-20) suggests that more empirical studies should be done to prove that deliberation can result in any of the following: (1) opinion change, (2) knowledge-gain, (3) post-deliberation behaviour and (4) other outcomes concerning tolerance for different opinions, sense of efficacy and satisfaction with the process and outcomes.

Ideal deliberation also led scholars to investigate the nuances of deliberation. Myers and Mendelberg (2013: 8-9) have cited the Discourse Quality Index (DQI) by Steenbergen et al. (2003) and the Stromer-Galley coding schemes as measures of adherence to the ideals of deliberation. These deliberative coding schemes have measures for equality, reasoning and respect in the deliberation process. The only difference is that DQI has a measure for consensus.

Stie (2008) has also zeroed in on the ideals in the actual conduct of the process as these serve as determinants of legitimacy. Accordingly, decisions that result in deliberation can only be considered legitimate if 
the participants can ensure the following: (1) inclusion of all the parties involved, (2) openness and transparency, (3) neutralisation of asymmetrical power relations, (4) deliberative meeting places and (5) decision-making capacity.

While the ideals presented are useful, the common criticism of the Habermasian discursive rules is that these ideals may be counterfactual and are more useful for critique (Gillespie et al. 2014: 73). Similarly, these ideals are all formed with the Western context in mind. As Min (2009) notes, caution must be exercised in applying Western ideals of deliberation in the context of the East. This could be the case for Filipinos whose communicative behaviours differ widely from other nationalities.

Communication scholars and anthropologists have noted the uniqueness of ways through which Filipinos communicate. Foremost, Filipinos value personalism (pakikipagkapwa) and familism (pagkakamaganak). They treat fellows as if they are members of their own families (Jocano 2001). Also evident is the tendency to seek credit for accomplishments, evade accountability (palusot) and go for the easiest and most convenient approach to doing things (Lacson 2005). In addition to these, it is common for Filipinos to get their message across in an indirect manner (pagpapahiwatig) through verbal (parinig or padaplis) and nonverbal (silence, raising of eyebrows, among others) codes. They also rely on third parties to communicate for them to avoid conflict (mensaheng may tagapamagitan). Moreover, there are cases wherein Filipinos maximise their capacity to verbalise their thoughts. They can disclose information about themselves (pagbubunyag) to trusted people (ipagtapat). Filipinos can confront other people (tuwirang pagsasagutan), but they will still choose their words, make segues and disclaimers before disagreeing. Unlike western cultures that have high regard for people who speak up, Filipinos consider silence as more value-laden and loaded. It may also indicate a negative response (Maggay 2002). These communicative behaviours are expected in any deliberations among Filipinos.

\section{PHILOSOPHICAL ANCHOR: GROUNDED PRACTICAL THEORY}

In 1989, Craig (cited in Craig and Tracy 1995: 251) deemed communication as a practical discipline with the need for studies that "cultivate communicative praxis or the practical art through critical study". In this 
regard, Craig and Tracy (1995) have sought to fill in the gaps of scientific theories that neglect the moral dimension of situated actions and normative theories that are considered difficult to operationalise and use in actual practice.

Drawing from Aristotle's work in ethics, politics and rhetoric as well as Dewey's and Gadamer's contribution to philosophy, Craig and Tracy (1995) conceptualised Grounded Practical Theory (GPT). Accordingly, GPT combines Aristotle's concepts of praxis, based on the moral and political aspects of practical discipline and techne, which covers technical and productive know-how. Moreover, GPT also considers the dialectical movement that actors take in the process of reflecting on their thoughts and actions - a process both forwarded by Dewey's pragmatic model of inquiry and Gadamer's hermeneutic circle.

GPT addresses the gaps in scientific theories and normative theories by addressing what "ought" to be based on systematically gathered data. In particular, GPT seeks for the rational reconstruction of a communicative practice or those where "the role of communication is not only important but presents complex problems that engage reflection on norms and values as well as technical means" (Craig and Tracy 2014: 230). This can be done through the study of three interrelated levels: (1) problem level this refers to the dilemma that actors are presented within the conduct of the communicative practice, (2) technical level - this comes after the identification of the problem and refers to the "discourse moves" or strategies employed by the actors to manage the dilemma, and (3) philosophical levels - this starts with what Craig and Tracy (1995) deem as "situated ideals" or the actor's belief as to how they "ought" to act in the communicative practice. The identification of communicative problems is the first step as it leads "downward" to the identification of communicative strategies that can address those problems and "upward" to the identification of situated ideals that serve as the overarching guide in choosing communicative strategies.

\section{METHODOLOGY}

This study has been conducted by using Action-Implicative Discourse Analysis (AIDA), which is the methodological arm of GPT (Tracy 1995). The first step in using AIDA is to name the practice under study. The practice chosen is named "budget deliberation", which is part of the LGU's 
budget authorisation phase (Department of Budget and Management 2016). As a methodology, AIDA entails long segments of talks that would permit the reconstruction of practice, analysis of data and reflection of communication actors (Tracy 2004, as cited in Konieczka 2013: 8892). Given these requisites, access to audio recordings of the budget deliberations in a rural municipality was requested. The recordings consist of 12 annual budget deliberations and 11 supplemental budget deliberations that occurred from 2013 to 2016 . The locale of the study is a second class municipality in the south of Manila. It is one of the municipalities with the highest estimates of poverty incidences in the province (Philippine Statistics Authority 2016) despite its income. Moreover, it exhibits potential for growth given its close proximity to a first-class city, a first-class municipality and a second class municipality (Bureau of Local Government Finance 2016) that have experienced extensive modernisation and development in recent years.

Table 1: Profiles of municipal council members

\begin{tabular}{clcc}
\hline Informant \# & Position & Sex & Length of service \\
\hline 1 & Vice Mayor & Male & Three terms \\
2 & $\begin{array}{l}\text { Council member, Current Chair of } \\
\text { the Committee on Finance, Budget, } \\
\text { Appropriation and Ways and Means }\end{array}$ & Male & Six terms \\
& $\begin{array}{l}\text { Former council member, Former Chair } \\
\text { of the Committee on Finance, Budget, } \\
3\end{array}$ & & \\
& Appropriation and Ways and Means & Five terms \\
4 & Council member & Male & Two terms \\
5 & Council member & Male & Two terms \\
6 & Council member & Female & One term \\
7 & Council member & Male & One term \\
8 & Council member & Male & One term \\
9 & Council member & Male & One term \\
\hline
\end{tabular}

The recordings have been transcribed and analysed to reveal the problems encountered and communicative strategies being employed during budget deliberations. The number of times each municipal council member spoke is also noted. Data from the preliminary analysis is used as guide in the semi-structured interviews with municipal council members. Copies of the transcribed talks are brought to aid in the semi-structured 
interviews. The municipal council members have been asked to read the transcribed talks to identify the problems, rationalise their use of particular communicative strategies and reflect on the local budget process. This method has resulted in the positive reconstruction of the communicative phenomenon of budget deliberation and helped identify the municipal council members' situated ideal.

In the conduct of the study, nine municipal council members are interviewed. The municipal council consists of seasoned and newly elected members. Their answers to the semi-structured interview questions are normally a combination of Filipino and English. For the purpose of this article, all answers have been translated into English.

Qualitative data is processed through codifying, which means that the data has been "segregated, grouped, regrouped and relinked in order to consolidate meaning and explanation" (Grbich 2007 as cited in Saldaña 2013: 8). In doing this, the researcher has followed Corbin and Strauss (2008) coding taxonomy. The constant comparative method is also employed throughout the analysis of data.

\section{RESULTS AND DISCUSSION}

\section{Communicative Problems in Budget Deliberation (Problem Level)}

Preliminary analysis of the transcribed talks provide an idea of the communicative problems that municipal council members encounter during budget deliberations. During their semi-structured interviews, the municipal council members also read the transcribed talks and were asked about what they thought were the communicative problems in their past budget deliberations. Accordingly, these included technicalities, lack of information and politics.

\section{Technicalities}

As described in the Budget Operations Manual of the Local Government Units (DBM 2016), the local budget process is composed of five parts: budget preparation, budget authorisation, budget review, budget execution and budget accountability. These come with technical documents produced by different units of the LGUs and submitted to different parties. These parts and documents are prerequisites that should be followed without deviations. For municipal council members, the process was said to be rigorous. 
Informant \#2: Municipal government, budget process, ah, basically it is by the book because it is written in the local government code and the limitations and boundaries all of that were stated in the Local Government Code or Republic Act 7160 where there are the guidelines that you have to abide by, budget process, budget implementation, the legislative authority or all of that.

Aside from the process per se, the guiding and resulting documents of the budget process were described as "technical" and could not be comprehended easily. This pertained specifically to the Local Government Code, the resolutions and ordinances whose legalese is also subject to different interpretations.

Informant \#3: There are cases that you have different interpretations. Sometimes, you could be reading the same questions, the same section which contains the same words, but you have different interpretations. That's difficult. Sometimes, there are arguments. I experienced arguing with someone. We are quoting the same section of the Local Government Code, but we have different perspectives, different interpretations, so that's one.

Technical terms in the budget documents prevented the municipal council members from actively deliberating the budget. It has been pointed out that the lack of capacity to understand the discussions which involved these documents would remain to be a perennial problem.

Informant \#2: Communicative problems, of course, communication should always be two-way. Now, if for example, I discuss something which the other party cannot comprehend, it becomes a perennial problem.... Of course, [there] is the inability of all the participants in the budget process to know all the terms, accounting terms. There are members of the municipal council who do not know all those terms and the importance of those. Also, we are here not because of our academic qualifications, but because of people's vote, the mandate of the citizens.

It can be said that the problem with technicalities serves as a driver of deliberation among municipal council members. As Dryzek and Niemeyer (2012) have reiterated, deliberation could be used to manage tensions between participation and expertise. In this case, those with expertise could provide the necessary guidance to facilitate the participation of other municipal council members. 


\section{Lack of Information}

Information is considered one of the prerequisites to successful deliberation (Fishkin 2009: ch 6). Gutmann and Thompson (2004) have supported this claim by pointing out the importance of access and capacity to provide reasons that can pave the way for continued deliberation. The absence of these prerequisites to deliberation has been seen as a problem.

Informant \#6: Like before, they did not give the details that we needed. Just like [them], we have the same stand, we want to know who will it [the budget] be for? Right? We are new here. We want to know literally all. I would not say it is my weakness that I'm new, rather I have the right as a councillor to know everything, or maybe not everything, at least $80 \%$ because that's very important, your one vote, that's very important because many people will be affected by your "yes" or "no".

\section{Politics}

A few of the municipal council members cited what they deemed as "politics" to be an inevitable problem during budget deliberation. This exemplifies the political nature of budgeting (Norton and Elson 2002). The exercise of force instead of reason in the evaluation of arguments could lead to problems and loss of opportunity to weigh the merits of the opposition (Cohen 1989: 22-23). Similarly, the existence of such force could also lead to judgmental constraints (Gutmann and Thompson 2004) in the sense that people could not reflect on their decision to concur or dissent on resolutions and/or ordinances.

Informant \#1: Frankly, politics. Politics. The budgeting deliberations, deliberations of budget, that's where politics enter, when the Mayor says he wants something, of course, he has a party of his own that [would pass the budget] even though it is not in favour of the people, that's what I see as the problem. What's dictated [by the Mayor], it'll be followed. I would always tell them, I will always remind them during budget deliberation, that they were voted by the people, their mandate should be with the citizens, not just with an individual. If we were to pass this [budget], it should be for the people, not for an individual. Frankly, that's it [politics]. 
Politics, particularly one's political inclination, serves as a barrier to communication during budget deliberation. Accordingly, someone's political inclination could prevent him or her from accepting the opinions of the other municipal council members. This could be related to what Gutmann and Thompson (2004) have referred to as dialogical constraints that are born out of one's reliance on personal opinions during deliberation. In this regard, Fishkin's (2009: ch. 6) prerequisite of equal consideration for arguments regardless of the source would not be possible.

Informant \#3: As a councillor, you know sometimes there are communicative [problems], but there are times, sometimes, it's not communication, but politics comes in. Sometimes, during deliberation, even when you can justify the use of a budget, why the said fund is needed, why it has to be approved, there are times that no matter how you justify it, if political partisanship prevails, it'll somehow be difficult for you to get the votes of your colleagues. That's number one. Aside from that, no matter how good you are at communicating, if the listeners are close-minded not because they do not understand, but because of politics, they won't accept your explanations.

While politics is considered an inevitable and inherent problem in budget deliberation, a member has perceived politics as a problem that could benefit democracy. As observed by Scudder (2016), dissent should be preferred over consensus because it can lead to better deliberation among participants. However, in this case, the Internal Rules of Procedures compelled the municipal council members to reach a consensus at the end of the deliberation.

Informant \#2: Of course, this is politics. Budgeting is politics. I propose that they make some contradiction. It'll always be that way. You'll be sponsoring, they'll be contradicting or vice versa, I'll be contradicting, they'll be sponsoring and because of that, there are some communicative problems. First is implied because of the nature of the topic - budget - implied because it should be healthy, it should be healthy if there are two parties that are not agreeing. At the end of the day, you'll all agree, at the end of the day, there is votation which may end up by majority or superior majority (sic). Now second is, incidental or accidental communicative problem that is because of politics, you really won't agree. As always, there are two conflicting parties and it is healthy in a democratic system of governance. 
The positive regard for politics is also shared by another seasoned municipal council member. Accordingly, politics could delay the budget process, but it could also provide an opportunity to scrutinise the budget in order to change and improve it.

Informant \#5: Usually, the problem here is politics, the things that you cannot agree on. We are pro-administration, of course, those [funds] are okay with us because we could not see anything wrong with the budget, but if you are against [the current administration], of course, you will scrutinise whatever you like. But usually, what happens in the municipal council is, everything gets passed despite delays. However, sometimes, the process gets mixed with politics. Sometimes, [at least] they can see things that need to be studied thoroughly.

Given the standards set by deliberative democrats, it could be said that the municipal budget deliberation is far from being considered as ideal. Two of the communicative problems identified are technicalities and lack of information. These problems make the municipal budget deliberation prone to deception, which should not be present in ideal speech situations (Habermas 2008, as cited in Gillespie et al. 2014: 73).

An even larger problem that surfaced is politics. Politics could affect the budget deliberation because it does not ensure the absence of coercion, which is one of Habermas' (2008, as cited in Gillespie et al. 2014: 73) requisites. Informant \#3 also reiterates that politics has brought the municipal council members into the budget deliberation with a closed and narrowed view of issues. Thus, politics could prevent parties from changing their positions - an outcome that Dryzek and Niemeyer (2012) expect from any deliberations.

\section{COMMUNICATIVE STRATEGIES TO ADDRESS COMMUNICATIVE PROBLEMS (TECHNICAL LEVEL)}

In order to address the problems of technicalities, lack of information and politics, the municipal council members employ communicative strategies. In the analysis of transcribed talks, 10 communicative strategies surfaced. Since GPT and AIDA involve the positive reconstruction of the communicative practice, municipal council members have been asked for the reasons behind employing the said strategies. 


\section{Code Switch}

Ordinances related to budget are written in English. To make sense of these ordinances, municipal council members commonly use their native language, Filipino. From time to time, they would also switch to English when thoughts are deemed easier to convey in the said language. Aside from convenience, the switch from Filipino to English and vice versa during budget deliberations is done to facilitate greater understanding among members. Moreover, switching to a more convenient language can serve as a means to get one's message across, especially in budget deliberations where technicalities of the processes and documents can form communicative barriers.

Informant \#3: There are times, sometimes, maybe you have to really express yourself in Tagalog, or you have to say it English, do code switching for them to get what you mean.

\section{Referral and Deferral}

The municipal council follows the "Three Reading Principle". For the First Reading, authors explain the proposed ordinance/resolutions and presiding officers refer it to appropriate committees while sponsorship and debate take place in the Second Reading and votes are made during the Third and Final Reading. This process permits members to refer budget ordinances to the Committee on Finance, Budget, Appropriation, and Ways and Means for review. Similarly, some members could defer the resolutions and ordinances to gather more information for support.

The municipal council members use the opposite communicative strategies of referral to achieve opposite goals. Referrals are made to fasttrack the passage of the resolutions and/ordinance. This is commonly done when members have questions that could be answered by other offices in the LGU.

Informant \#3: So there are times when there are questions that we cannot answer, so as not to prolong [the discussion], I would tell them that it is not the concern of the municipal council, so let's ask the office that can answer. 
As for deferral, this communicative strategy has been employed to stall the passage of the resolutions/or ordinances. Since the lack of information has been identified as a problem, deferrals allow one more time to gather data and weigh the merits of arguments in support or in opposition to the resolutions and/or ordinances. Deferral as a strategy can be used to provide more time for municipal council members to evaluate their stand and for authors and sponsors to get the number of votes that they needed for their resolutions and/or ordinances.

Informant \#2: You have to defer because maybe, tomorrow or the next day, your colleagues will change their minds. Maybe you can get the number [of votes]. So you'll use some strategy to buy some time. Maybe, eventually, members of the council might encounter citizens who will give them some information. Maybe later, even when they're also opposing, they'll eventually join you because you really need your number [of voters].

\section{Establishment of Openness, Assertion of Competence, and Making a Plea}

In the Internal Rules of Procedures, a municipal council member who is reporting or sponsoring a measure (in this case, a budget ordinance) is given 20 minutes to open or close the debate. The said member starts with reading the whole or some parts of the ordinance with background information from the different offices. After this, other municipal council members are allowed to ask questions. In budget ordinances, opening and closing are done by a municipal council member who is also a part of the Committee on Finance, Budget, Appropriation, and Ways and Means. This strategy serves as an opportunity for authors and sponsors to display their technical knowledge in the municipal budget process as well as to ensure that the Committee on Finance, Budget, Appropriation, and Ways and Means has completely scrutinised the ordinance. These steps are followed by a plea to the other municipal council members to approve the ordinance.

Informant \#3: Because number 1, that's the essence of being a councilor, a legislator, for you to introduce measures, resolutions, ordinances. For you to do it, you really have to study what you'll present to them. Otherwise, how else will you convince them to vote or to go with you and your proposal? Remember, it is a council. 
You cannot pass an ordinance alone unless you get the vote of the majority. In order to do that, you have to convince everybody that your proposal is great, that it will benefit everyone. So you need to study and study extensively the contents of your proposal. Aside from that, it also becomes the basis of whether you'll convince your colleagues to join you in your proposal. Also, of course, your knowledge does not end with the approval of the municipal council. After it turns into an ordinance, it will become local law. There are times that people will ask you outside about the resolutions and ordinances that you passed. It'll be shameful if you cannot explain what you passed in the municipal council. It's very important that as a legislator you know how to study, I turned the Local Government Code into a bible because it's the basis of our work in the government, so you have to know it.

\section{Clarification and Suggestion}

Since budget ordinances are filled with technical information, deliberation is dominantly characterised and sustained through clarifications and suggestions. For the municipal council members, clarifications and suggestions are made to achieve the following goals: justification, scrutiny and conduct of duty. It is considered a must to engage in a series of clarifications and suggestions to explain why the committee supported the resolutions and/or ordinances and how they dissected every item in the budget. This communicative strategy could also benefit from the knowledge of government laws.

Informant \#3: There are times that you have to justify every item included in the budget, in the general fund. Why? Since we have different political inclinations, there are times that one will say we do not need to allocate a budget there or we can eliminate this, there are times when [they will say] "this is huge, let's deduct", so I have to clarify, to explain the need of the municipality to allocate a budget for this particular item. I have to convince them that we need this. "Let's not withdraw the budget for this". "We need to allocate funds for this programme and everything". So in order for me to do that, I have to justify, explain. Sometimes I even have to use basis, like guidelines or other national laws just to prove to them that "the town needs this". "We need to fund this". For them to realise it, that it's okay that we need this [so] let's vote for this. That's it, basically. 
Clarification and suggestions also offer an opportunity for the opposition to explore all the details of the budget, raise hidden agenda and ensure that the budget has complied with the technical and legal requisites. Accordingly, the clarification and suggestions have also provided the members with answers to inquiries from constituents who should be benefitting from the budget process.

Informant \#2: Last term I was in the opposition, more of a hardliner opposition, so I would always look at the budget process as a way for me to express my sentiments or dissent. Although there are some instances that you need to support projects because it's good for the community, then again there are issues in the actual budget that are hidden. So as part of the opposition, I look at it as something that should not be there and if it should be there, it should be regulated. There should be clear cut lines as to how to spend them, which was why I brought up discussions on the technicalities of the budget. Is it needed? Do we need it? And if it is needed, does the law allow it? Because that is the thing, maybe we need it, but the COA (Commission on Audit) and other budgetary regulators would not permit it. Background information is important because the budget is the lifeblood of the government and as members of the municipal council, it is our obligation and responsibility to know all of that because one day you're walking and somebody asks you why the public market has not been fixed? You do not know the answer, so you will refer back to the annual budget. There is a budget, but the difference is we give the legislative authority to the executive, but the executive is not executing it. What can you do? So which is [why] you have to know all the details in the budget, so when regular people ask, you can answer because it is their right to know the answer from you because they elected you.

\section{Repetition}

In order to understand and make sense of the technical data in the budget ordinances, the municipal council members also resorted to the repetition of parts of the resolutions and/or ordinances tackled in the past or in the present to facilitate comprehension and yield well-informed decisions in the current budget deliberation. Repetition is also done with the goal of influencing programme municipal council members to rationalise and optimise the budget in order to address the neglected needs of the municipality. 
Informant \#2: Just to remind them that before there are some appropriations of similar nature and to show that there is no need or that. It is irrelevant to make some appropriation on an item which has been appropriated on or which has allocated funds before because it will provide an excess of funds. There should be other priorities in the local government that should have been allotted with funds.

\section{Show of Empathy for Constituents}

Psychologist Carl Rogers (1959, as cited in Rogers 1995 : 140) defines empathy or being empathic as a state wherein one "perceived the internal frame of reference of another with accuracy and with the emotional components and meanings which pertain thereto as one". It is akin to what Jocano (2001) regards as personalism (pakikipagkapwa) and familism (pagkakamag-anak). A municipal council member shows empathy to constituents by reflecting on their social realities. These reflections are also articulated during budget deliberation with the desire to make fellow municipal council members empathic towards constituents. Accordingly, the show of empathy for constituents makes it possible to give a voice to neglected stakeholders of the municipality. In this particular case, the subjects of empathy are non-regular employees.

Informant \#2: Remember daycare workers, they nurture the children at a very young age, but they are receiving less. There should have been a higher salary for them. The same thing is with municipal government workers in the agricultural sector. They are all job orders. They are not regular workers. They are low in terms of salary. You have to protect them. I believe that in the annual budget, their concern should be protected and should be brought into the discussion. This was why in that topic, that was the supplemental budget last year, I believed they were being neglected by the officials because if you would look at the annual budget of the municipal hall, the employee's salary had increased, but they were not included. Why? Because they are job orders and daycare centres are receiving only financial assistance. So they're not protected by the salary standardisation that's mandated by the law. 


\section{Sarcasm}

There are also municipal council members who resort to sarcasm to emphasise their opinions on budget ordinances and the technical rigidity that comes with it. This is an example of Filipino communicative behaviour that is verbal (parinig or padaplis) but also indirect (Maggay 2002). Sarcasm during budget deliberation is done to achieve two opposite goals: fast-track or stall the deliberation. Since budget deliberation can be prolonged, one could resort to sarcasm to signal the need to terminate or speed up the budget deliberation.

Informant \#3: You know sometimes that really exists in all deliberations of a legislative body like the ones we see in Congress, in the Senate, among legislators. [It happens] when you're a bit exhausted in explaining and everything, especially if you think that you are explaining something so obvious like it does not need to be explained, but you are still questioned only for the sake of questioning. Sometimes you cannot help but resort to sarcasm just for them to stop asking.

Contrary to the use of sarcasm to fast-track the budget deliberation, it could also be used to stall the budget deliberation. Accordingly, sarcasm serves as a means to get messages across whenever one has felt opposition toward his or her opinion. It could also spark attention to the resolutions and/or ordinances being discussed.

Informant \#2: Another strategy is to make your opponents blow their heads. You need to do that because first, your back is against the wall and you cannot do anything else in terms of numbers and figures. So even in sports, you make dirty tactics, but that one [sarcasm] is rhetoric in order to make the discussion more active and participative. I believe that in all activities in life, you have to strategise. That's part of the strategy.

\section{Redirection and Restriction}

The Internal Rules of Procedures permit municipal council members to ask and answer questions about the resolutions and ordinances. The same rules also allow them to decline to answer questions as they please. In some instances, municipal council members may redirect the others by pointing out what the resolutions and ordinances are about. 
Aside from redirection, the municipal council members can restrict another member from speaking since it is supported by the Internal Rules of Procedures, particularly the "Third Reading Principle" wherein they may only debate and amend on the Second Reading. For the municipal council members, both redirection and restriction ensured that budget deliberations are conducted according to the rules.

Informant \#1: It's the flow of the municipal council, that's how it usually runs in the municipal council, uhm, we have our internal rules, those rules need to be implemented, so as a presiding officer, one of my tasks is to make sure that the flow of the session is orderly.

Redirection and restriction also come in handy when there is a need to fasttrack the approval of the resolutions and/or ordinances. They provide more attention to the task at hand and allow the municipal council members to finish quickly, so they can attend to other matters.

Informant \#7: Because when it is out of topic, we won't finish discussing what we need to discuss, so we should first finish this before we move to the topic that they want us to talk about because we won't finish if we jump from one topic to another. We need to focus on this first.

\section{Silence}

While quorum is required to push through with budget deliberations, it has been observed that not all municipal council members would speak up or voice their opinions during the debates and amendments. Instead, participation is only made through non-verbal gestures of raising one's hand to show concurrence or dissent toward budget resolutions and/or ordinances.

The communicative strategy of silence is common among newly elected municipal council members. Since budget deliberations involve issues of technicalities, lack of information and politics, the newly elected municipal council members prefer to observe and learn the norms from more seasoned members. They resort to silence in order not to curtail the flow of budget deliberations.

Informant \#6: I was silent the whole time because I do not want to meddle on things that I do not know. Right? I am new. I know where I stand and I know where I'm coming from. That's why I do not want 
to endorse myself like I know this, I know that and everything when the truth is, I'm still learning. Right?

Informant \#9: I'm a first-term councillor like I said... In 2016, I've been studying the rules and I've been studying the process because I'm still young in the field of politics. That's why I'm silent.

Silence can also mean that one concurs with the proposed budget. It exemplifies trust in the system wherein other municipal council members have studied the resolutions and/or ordinances well.

Informant \#8: I'm silent because most of the time, I agree with the Mayor's proposal. I do not oppose it. I can see that it's okay. It is being studied. It was also studied before we discussed it. I bring the minutes at home to study.

For the seasoned municipal council members, they choose to be silent because of three things: dissent, lack of information and urgency. Silence is used when one's views are considered unpopular.

Informant \#4: What happens is if you are not pleased with the way the deliberation is taking course, you'd just be silent. When you want to say something, it won't happen anyway because the majority gets to decide. That's why it's better to just be silent, so that there won't be arguments during deliberation. What happens here is argumentation, that's why it's better to just be silent, keep it with you. If you have ways, like what we did, that was legal. [Be silent] so that there won't be chaos during the discussion.

Among the communicative strategies, silence can mean several things for Filipinos. It can be the municipal council members' convenient approach (Lacson 2005) to get the budget deliberation off their shoulders. They can also be silent because they rely instead on the knowledgeable ones to speak on their behalf and avoid scrutiny (mensaheng tagapamagitan) (Maggay 2002).

\section{Termination}

Depending on the course of budget deliberations, any one of the members may move for its closure. This communicative strategy prompts the municipal council members to decide on the budget resolutions and/or ordinances. Termination can come in the form of seconding or voting for the 
approval of the resolutions and/or ordinances. Similar to the communicative strategies of redirecting and restricting, terminating through seconding or voting is being done as a matter of policy. According to the Internal Rules of Procedures, municipal council members can move for the closure of the debate through voting. Accordingly, it is a way to reach consensus despite varying opinions on the budget resolutions and/or ordinances.

Informant \#7: That's why we need votation because here, although we have different opinions, it's always "majority wins", and we respect the majority. Sometimes, I'm with the minority, most times with the majority. We have our own opinions when it comes to that, that's why we put it on votation.

Moving for closure through votation is also part of the process and the tasks of the municipal council members. For those in charge, it could serve as an affirmation of the effort exerted toward studying the resolutions and/or ordinances.

Informant \#3: As chairman of the committee on finance, it is your duty to see to it that the budget will be passed accordingly because it is important. The government will suffer without a budget and I also said the budget had been studied. Once it's been studied, you know that what's being proposed is not contradictory and it's always according to laws, rules and regulations. We have budgetary limitations; we have budgetary requirements in the Local Government Code. As long as the budget adheres to that, there is no reason for you not to approve the fund. So as chairman of the committee on finance, it is your duty to see to it that the budget will be passed for a smooth flow of the government's processes.

In the description and the rationalisation of the communicative strategies, it can be said that the municipal council members' conduct of budget deliberations has been guided by the Internal Rules of Procedures. The existence of the Internal Rules of Procedures is akin to Mummery and Rodan's (2013: 36-37) suggestion that such guidelines are needed despite expected participation and manageable barriers.

It has also been found that socio-psychological functions could explain one's behaviour during deliberation, as pointed out by Rutsaert et al. (2015: 197-198). The importance of cognition is evident in budget deliberations, particularly in the use of code-switching, repetition and clarification and suggestion. Along with the communicative strategies of 
referral and deferral, the previously mentioned strategies are also considered as modes that permit disagreements (Polleta 2008, cited in Myers and Mendelberg 2013: 16). At the same time, these communicative strategies also serve as a means of creating understanding among the municipal council members.

Moreover, the communicative strategy that combines the establishment of openness, the assertion of competence and plea-making has allowed the authors and sponsors to make other municipal council members see their shared objectives and align with their views of the budget, in line with the deliberation strategy found by Jacson and Tan (2013: 23) and Kenter et al. (2016: 288) in their respective studies. The said strategy and silence are also employed to perpetuate the political status quo, which is deemed by Ojha et al. (2009: 373) as one of the functions of deliberations. Similar to termination, the communicative strategies described here also exemplify the municipal council members' decision-oriented deliberation as comparable to the networks described by Van de Ven et al. (2017).

While the budget deliberation does not involve citizens, the idea of citizens' interpretation (Degeling et al. 2016, 117) is somehow present as the municipal council members have shown empathy in their consideration of citizens' concerns during budget deliberations. Lastly, the communicative strategy of sarcasm is also found. This is the least studied communicative strategy during budget deliberations. Nevertheless, this strategy is still employed despite negative connotations.

\section{NORMATIVE COMMUNICATION PRACTICES OR SITUATED IDEALS FOR MORE EFFECTIVE BUDGET DELIBERATIONS (PHILOSOPHICAL LEVEL)}

Through the analysis of the transcribed talks and the rationalisations made during the semi-structured interviews with the municipal council members, three overarching reasons have been uncovered as drivers for the use of a particular communicative strategy.

With the use of different communicative strategies, it can be said that the Municipal Council Members are placed in what Habermas (1981, as cited in White 1988) deems as an ideal speech situation in the sense that they are allowed to participate through speech and action in the budget deliberation. 
Table 2: Reasons for using a communicative strategy

\begin{tabular}{ll}
\hline Communicative strategy & Reason \\
\hline Code switch & For comprehension or dissection \\
Referral & For fast-tracking \\
Deferral & For stalling \\
Establishment of openness, assertion & For comprehension and fast-tracking \\
of competence and making a plea & \\
Clarification and suggestion & For comprehension or dissection \\
Repetition & For comprehension or dissection \\
Show of empathy for constituents & For comprehension or dissection \\
Sarcasm & For stalling or fast-tracking \\
Redirection and restriction & For fast-tracking and/or consensus \\
Silence & For fast-tracking and/or consensus \\
Termination & For fast-tracking and/or consensus \\
\hline
\end{tabular}

However, the communicative practice of budget deliberation in the municipality can also be subjected to the same critique as that of Habermas' ideal speech situation. In the process of analysing the communicative problems encountered by the municipal council members, technicalities, lack of information and politics have been cited as barriers that prevented them or their fellow members from engaging in budget deliberations. In addition to these communicative problems, budget deliberations only considered majority votes as a legitimising measure. This is in stark contrast with Stie's study (2008), which considers the following as determinants of legitimacy: (1) inclusion of all the parties involved, (2) openness and transparency, (3) neutralisation of asymmetrical power relations, (4) deliberative meeting places and (5) decision-making capacity. Given the problems of technicalities, lack of information and politics, these determinants have not been met by the municipal budget deliberation, with the exception of the 4 th and the 5 th.

Despite these communicative and legitimacy problems, the municipal council members have employed communicative strategies that would help them achieve their situated ideal of duty-centred budget deliberation. The municipal council members' notions of their duty as elected officials propell them to employ the mentioned communicative strategies. For those who use several communicative strategies for comprehension or dissection as well as stalling communicative strategies, their duty is to scrutinise the budget and know all the details because they are accountable to the constituents. As Informant \#7 stresses, "I did not want to leave the 
office without answers to my constituents, especially since they would ask, 'What is this?' or 'How did this happen?' I prefer that when I get out of the office, I know the answers". For Informant \#3, communicative strategies that allow for comprehension and dissection also permit municipal council members to pass a sensible budget. She states, "Yes, you have to pass the budget, but it should be a budget with justifiable reasons. It is needed by the municipality. It is needed by the constituents. It should be well-planned and well-thought-out".

Meanwhile, there are municipal council members who feel that it is their duty to ensure the urgent approval of the resolutions or ordinance. This has resulted in the use of communicative strategies for fast-tracking. Urgency is asserted as the absence of funds could derail the operations of the municipal government. There's also the belief that the risks inherent in the absence or limited scrutiny of the budget would be mitigated by the existing laws and regulatory bodies. This has been pointed out by Informant \#3: "It is your duty to see to it that the budget will be passed accordingly because it is important. The government will suffer without a budget".

In all of these deliberations, the municipal council members have insisted that they put the welfare of the constituents as they participate in the communicative practice of budget deliberation and they are fine with the outcomes. On average, only $40 \%$ of the budget is allotted to personal services, $34 \%$ to operations and capital outlays and $26 \%$ to special purposes such as the economic development fund, calamity fund, support to the villages (barangays) and aid to a local public university. Supplemental budget augments the operational expenses and maintenance of government facilities and infrastructure, mainly in the municipal centre or poblacion.

Based on the reasons for the communicative strategies, a normative model of duty-centred budget deliberation could be derived to answer the question about how municipal council members ought to communicate during budget deliberations.

This normative model includes the following communicative strategies: (1) code switch, (2) referral and deferral, (3) establishment of openness, assertion of competence and making a plea, (4) clarification and suggestion, (5) repetition, (6) show of empathy for constituents, (7) redirection and restriction, and (8) termination. These communicative strategies are considered for several reasons. Stie (2008) emphasises the need for transparency in deliberation. Hence, it is imperative to include the use of referral and deferral, clarification and suggestion and repetition 
because these communicative strategies permit the scrutiny of information during budget deliberations. These communicative strategies could also lead to more understanding, which Gutmann and Thompson (1996, as cited in Myers and Mendelberg 2013) deem as the desired outcome of deliberation.

It is also for the aforementioned reasons that the communicative strategy of silence has been excluded from the normative model. The context of the municipal budget deliberation exemplifies Maggay's (2002) assertion that silence may be indicative of negative response for those who use it. In the aforementioned discussion on silence, Informants \#6, \#8 and \#9, who are newly elected council members, have resorted to silence because of their inadequate experience in the municipal budget deliberation process. Informant \#3 has suggested that they should avoid silence and equip themselves with knowledge from the Local Government Code. She stresses, "I'd always say they should learn to read the Local Government Code because everything that they need to learn about budgeting and managing finances can be found there... It is only their first year and they just experienced one budgeting period. Hopefully, it will get better for them. They should not be silent. They have to speak up". For Informant \#4, his silence is his way of showing that he is not pleased but he could not do anything about it because approval depends on the vote of the majority. While silence is indicative of a negative response in the context of municipal budget deliberation, it has been noted that the said communicative strategy also shows the Filipino predilection to be non-verbal and the importance placed on personalism (pakikipagkapwa) and familism (pagkakamag-anak) (Jocano 2001).

Inclusiveness is also a commonly held ideal in deliberation (Habermas 2008, as cited in Gillespie et al. 2014: 73; Stie 2008). The switch to a more comprehendible language, the assurance of openness and the show of empathy for constituents are communicative strategies that attempt to include parties into the deliberation. Meanwhile, the assertion of competence both in the individual and committee level is also welcome as it produces an environment of self-knowledge and access to information, which are requisites of deliberations (Mezirow 1985: 144).

Included also in the communicative strategies of the normative model are redirection and restriction. Offhand, this may be seen as a mechanism to curtail the freedom of speech during deliberation. However, based on the semi-structured interviews, redirection and restriction are ways of refocusing on priority issues during the deliberation. If conducted properly, 
these communicative strategies could establish respect, a key variable being measured when assessing the quality of discourse (Myers and Mendelberg 2013). The same applies to the communicative strategy of making a plea. By requesting fellow municipal council members to consider the proposal, the municipal council member who has presented or proposed the budgetary resolutions and/or ordinances recognises the importance of going through the process of municipal budget deliberation. It is in consideration for the key measure of respect that the communicative strategy of sarcasm has been excluded from the normative model. Informant \#2, who has resorted to sarcasm, recognises it as an example of "dirty tactic" to achieve the desired outcomes. Sarcasm is contrary to common Filipino values of personalism (pakikipagkapwa) and familism (pagkakamag-anak) that often guide how Filipinos communicate with each other.

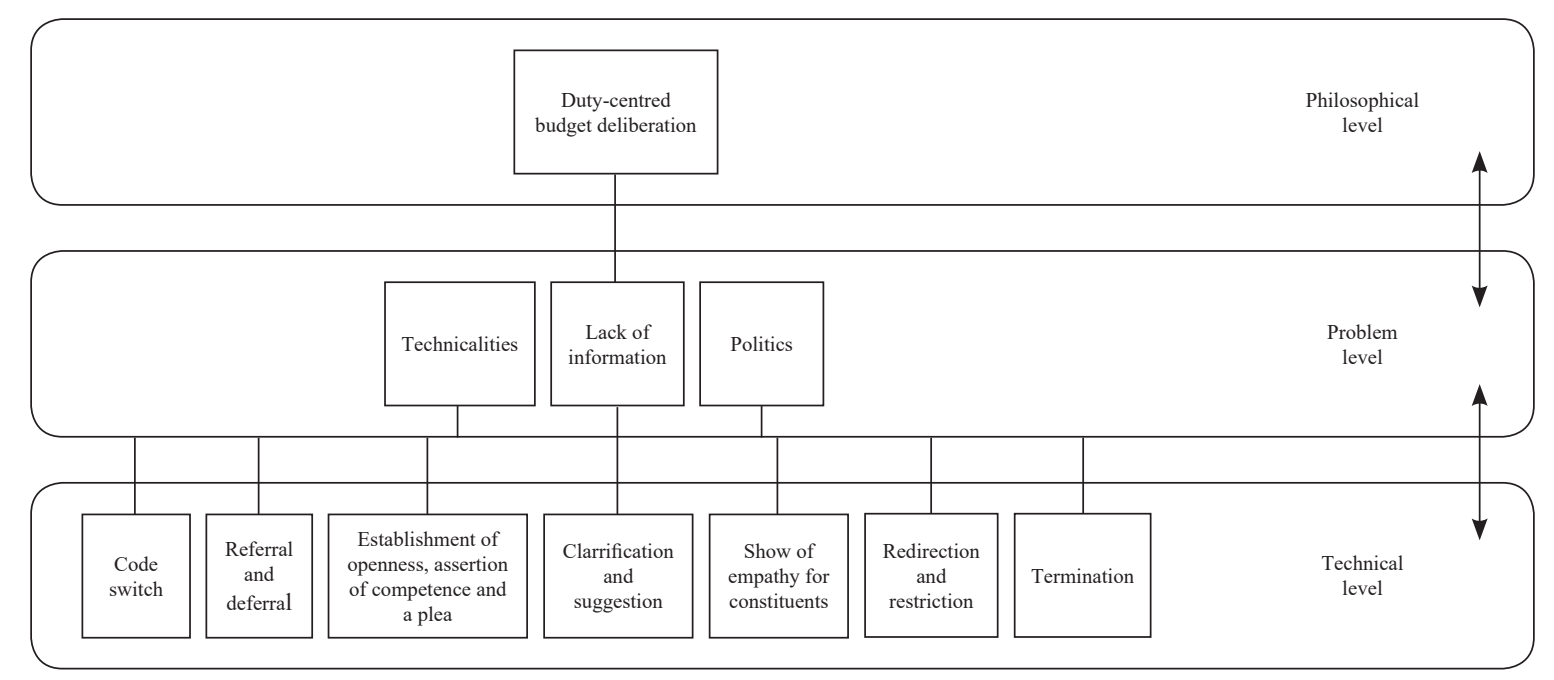

Figure 1: Normative model of duty-centred budget deliberation.

The last communicative strategy that has been included is termination. It is deemed important because it prompts the decision-making during budget deliberations. While there are varying recommendations about the desired outcomes of deliberation, Scudder (2016) favours consensus, which can be achieved through votation during the municipal budget deliberation. The communicative strategy of termination should not pose a problem if it is done according to Fishkin's (2009: ch. 6) premise that arguments can be assessed based on merits. 


\section{CONCLUSION}

Through the data analysis of transcribed talks and semi-structured interviews, three problems that the municipal council members encountered during budget deliberations surfaced: (1) technicalities of the budget process and documents, (2) lack of information and (3) politics.

To address these problems, they have employed communicative strategies to facilitate comprehension and/or consensus, stall, or fast-track the budget deliberation, namely: (1) code switch, (2) referral and deferral, (3) establishment of openness, assertion of competence and making a plea, (4) clarification and suggestion, (5) repetition, (6) show of empathy for constituents, (7) sarcasm, (8) redirection and restriction, (9) silence and (10) termination. These communicative strategies are also used to achieve the situated ideal of duty-centred budget deliberation minus sarcasm and silence.

While the budget deliberation as communicative practice might be considered imperfect based on the standards of deliberative democracy, this article nonetheless highlights its usefulness in the exploration of the the municipal council members' situated ideal. The study demonstrates that despite communicative problems, the municipal council members have employed communicative strategies that best address the problems that they encounter and ultimately, help them carry out what they consider as their duties. In a way, the study provides a reflection and rationalisation embedded in the communicative practice of budget deliberation.

By reflecting on the problems, strategies and situated ideals, the municipal council members have realised that much can still be improved in the budget deliberation and the budget process in general. Improvements revolve around the need for transparency, which could be achieved by disclosing every item in the budgetary documents, providing progress reports for the past projects, programmes and activities where the budget has been appropriated, and conducting a series of fora with the local chief executive. These suggested improvements mean that while the municipal council members conduct the budget deliberation, an effective and efficient budget process could be achieved if they are also informed and updated for the whole budget cycle.

In the conduct of the study, the pragmatic lens of GPT provides an understanding of the incommensurability that occurs during budget deliberations. However, a study of budget deliberations with consideration of the philosophical and socio-political underpinnings of competing 
positivist and constructivist paradigms should also be welcomed. In particular, future researchers may also assess municipal budget deliberations using quantitative indexes such as the Discourse Quality Index (Steenbergen et al. 2003). A hypthetico-deductive approach would also establish causalities among factors that contribute to the success or failure of municipal budget deliberations. A cultural lens may also be used. Since budget deliberations are embedded in the culture of the municipality, it would pay to study the organisation of the municipal government to further understand the nuances of its budget process. It is also imperative to look at municipal budget deliberations with a critical lens because it is set in a political environment where power plays a key role.

Also, while this article analyses the naturally occurring data through the transcribed talks that are further informed by semi-structured interviews, it can benefit from the use of participant observation. The said method will yield more extensive and more grounded data since it will cover non-verbal codes. Participant observation will also be useful to those who consider the end-to-end analysis of the entire municipal budget process, not just the budget authorisation phase, where the municipal budget deliberations take place. Participant observation could provide future researchers with the opportunity to hear off-the-record conversations during recess. Exploration of such conversations could be informative, especially if the objective is to study muted voices in budget deliberations.

Overall, this study has managed to come up with the descriptions of the communicative practice and the normative model of duty-centered budget deliberation despite its limitations. Since the findings are based on data, they are unlikely to suffer from counterfactualism, which Gillespie et al. (2014) have pointed out in the set of ideals for deliberation. The findings also partially address Min's (2009) concern regarding the use of Western ideals of deliberation in the context of the East. Since this article relies on transcribed talks, there is a need to conduct participant observations to understand non-verbal codes that are prevalent in Filipino communicative behaviours. Moreover, this research was conducted in just one municipality where the descriptions and the normative model are plausible. Similar undertakings must be done in other municipalities and cities, particularly those classified as 1st class and 6th class, to understand the dynamics of municipal budgeting with either ample or limited resources. These undertakings could help the municipal council members reflect and improve their budget process and as a result, improve their governance. 


\section{ACKNOWLEDGEMENTS}

The author wishes to thank the members of her advisory committee at the University of the Philippines Los Baños: Dr. Serlie Barroga-Jamias, Dr. Alexander G. Flor and Prof. Girlie Nora A. Abrigo. Their insights guided the conduct of the research that served as the basis of this journal article.

\section{NOTES}

* Louise Antonette S. Villanueva obtained her bachelor's degree in Communication Research from the University of the Philippines Diliman and her master's degree in Development Communication cognate in Sociology from the University of the Philippines Los Baños where she is serving as Assistant Professor. At the College of Development Communication, she handles courses in critical perspectives in communication, interpersonal communication, distance learning, media and society and community broadcasting. Her research interests include development communication, life course, governance and rural sociology.

\section{REFERENCES}

Asian Development Bank. 2013. Philippines: Local Government Financing and Budget Reform Program Cluster. https://www.adb.org/sites/default/files/projectdocument/75494/39516-023-phi-pcr.pdf (accessed 11 April 2020).

Black, L. W. 2009. Listening to the city: Difference, identity, and storytelling in online deliberative groups. Journal of Public Deliberation 5 (1): Article 4. https://doi .org/10.16997/jdd.76

Blondal, J. R. 2010. Budgeting in the Philippines. OECD Journal on Budgeting 2: 1-22. https://doi.org/10.1787/budget-10-5km7rqpf57hb

Bureau of Local Government Finance. 2016. Income classification per DOF order no. 2308, dated July 29, 2008. https://blgf.gov.ph/wp-content/uploads/2016/10/updatedreclass-CY-2008-4-27-16.pdf (accessed 28 August 2020).

Cohen, J. 1989. Deliberation and democratic legitimacy. In The good polity: Normative analysis of the state, eds. Hamlin, H. and Pettit, P., 17-34. New York: Basil Blackwell.

Corbin, J. and Strauss, A. 2008. Basics of qualitative research: Techniques and procedures for developing grounded theory. 3rd ed. Thousand Oaks, CA: Sage Publications, Inc. https://doi.org/10.4135/9781452230153

Craig, R. T. 1989. Communication as a practical discipline. Rethinking Communication 1: $97-122$.

. 2014. Building grounded practical theory in applied communication research: Introduction to the special issue. Journal of Applied Communication Research 42 (3): 229-243. https://doi.org/10.1080/00909882.2014.916410 
Craig, R. T. and Tracy, K. 1995. Grounded practical theory: The case ofintellectual discussion. Communication Theory 5 (3): 248-272. https://doi.org/10.1111/j.1468-2885.1995. tb00108.x

Curato, N., Dryzek, J. S., Ercan, S. A., Hendriks, C. M. and Niemeyer, S. 2017. Twelve key findings in deliberative democracy research. In Daedalus 146 (3): 28-38. https://doi.org/10.1162/DAED_a_00444

Degeling, C., Carter, S. M. and Rychetnik, L. 2016. Which public and why deliberate?: A scoping review of public deliberation in public health and health policy research. Social Sciences and Medicine 131: 114-121. https://doi.org/10.1016/j. socscimed.2015.03.009

Department of Budget and Management. 2011. Guidelines in determining compliance to the personal services (PS) limitation on local government budgets. https://www. dbm.gov.ph/wp-content/uploads/Issuances/2011/Local\%20Budget\%20Circular/ LBC98/LBC98.pdf (accessed 11 April 2020).

2016. Budget operations manual for Local Government Units. http://www.dbm. gov.ph/wp-content/uploads/Issuances/2016/Local\%20Budget\%20Circular/LBC112-BOM-inside\%20pages-correct\%20paging-FINAL.pdf (accessed 11 April 2020).

Day, M. M. 1993. Habermasian ideal speech: (Im)possible dream. http://ro.uow.edu.au/ cgi/viewcontent.cgi?article=1099\&context=accfinwp (accessed 11 April 2020).

Dryzek, J. and Niemeyer, S. 2012. What is deliberative democracy? http://deldem.weblogs. anu.edu.au/2012/02/15/what-is-deliberative-democracy/ (accessed 11 April 2020).

Dryzek, J. and Pickering, J. 2017. Deliberation as a catalyst for reflexive environmental governance. Ecological Economics 131: 353-360. https://doi.org/10.1016/j .ecolecon.2016.09.011

Dutwin, D. 2003. The character of deliberation: Equality, argument, and the formation of public opinion. International Journal of Public Opinion Research 15 (3): 239-264. https://doi.org/10.1093/ijpor/15.3.239

Fishkin, J. S. 2009. When the people speak: Deliberative democracy and public consultation. Oxford: Oxford University Press.

Gillespie, A. et al. 2014. Beyond ideal speech situations: Adapting to communication asymmetries in healthcare. Journal of Health Psychology 19 (1): 72-78. https://doi.org/10.1177/1359105313500251

Gonçalves, S. 2014. The effects of participatory budgeting on municipal expenditures and infant mortality in Brazil. World Development 53: 94-110. https://doi.org/ 10.1016/j.worlddev.2013.01.009

Gutmann, A. and Thompson, D. F. 1996. Democracy and disagreement. Cambridge, MA: Harvard University Press. 2004. Why deliberative democracy. New Jersey: Princeton University Press.

Grbich, C. 2007. Qualitative data analysis: An introduction. Thousand Oaks, CA: Sage.

Habermas, J. 1981. The theory of communicative action. Cambridge, UK: Polity. 2008. Between naturalism and reli-gion: Philosophical essays. Cambridge, UK: Polity.

Holdo, M. 2016. Deliberative capital: Recognition in participatory budgeting. Critical Policy Studies 10 (4): 391-409. https://doi.org/10.1080/19460171.2015.1077718 
Jacson, M. O. and Tan, X. 2013. Deliberation, disclosure of information, and voting. Journal of Economic Theory 148 (1): 2-30. https://doi.org/10.1016/j.jet.2012.12.002

Jocano, F. L. 2001. Filipino worldview: Ethnography of local knowledge. Quezon City, Philippines: PUNLAD Research House.

Kenter, J. O. et al. 2016. The impact of information, value-deliberation and groupbased decision-making on values for ecosystem services: Integrating deliberative monetary valuation and storytelling. Ecosystem Services 21: 270-290. https://doi. org/10.1016/j.ecoser.2016.06.006

Konieczka, S. P. 2013. Grounding governance in floating stakeholders: Theory and communication, collectivity, and relational transformation in practice; An ethnographic and discourse-analytic case study. PhD diss, University of Colorado.

Kyj, L. and Parker, R. J. 2008. Antecedents of budget participation: Leadership style, information asymmetry, and evaluative use of budget. ABACUS 44 (4): 423-442. https://doi.org/10.1111/j.1467-6281.2008.00270.x

Lacson, J. R. 2005. Mindsets of the Filipino: A research agenda for Filipino communicative behavior. Modesto Farolan Professorial Chair paper, University of the Philippines.

Leach-López, M. A., Stammerjohan, W. W. and McNair, F. M. 2007. Differences in the role of job-relevant information in the budget participation-performance relationship among U.S. and Mexican managers: A question of culture or communication. Journal of Management Accounting Research 19 (1): 105-136. https://doi. org/10.2308/jmar.2007.19.1.105

Maggay, M. P. 2002. Pahiwatig: Kagawiang pangkomunikasyon ng Filipino. Quezon City, Philippines: Ateneo de Manila University Press.

Mezirow, J. 1985. Concept and action in adult education. Adult Education Quarterly 35 (3): 142-151. https://doi.org/10.1177/0001848185035003003

Min, S. J. 2009. Deliberation, East meets West: Exploring the cultural dimension of citizen deliberation. PhD diss., Ohio State University, USA.

Mummery, J. and Rodan, D. 2013. The role of blogging in public deliberation and democracy. Discourse, Context and Media 2 (1): 22-39. https://doi.org/10.1016/ j.dcm.2012.12.003

Municipal Research and Services Center. 1999. Local government policy-making process. http://eatbettermovemore.org/sa/policies/pdftext/LocalPolicymakingProcess.pdf (accessed 11 April 2020).

Myers, C. D. and Mendelberg, T. 2013. Political deliberation. In Oxford handbook of political psychology, eds. Huddy, L., Sears, O. and Levy, J. S, 2nd ed., 1-27. New York: Oxford University Press.

Norton, A. and Elson, D. 2002. What's behind the budget? Politics, rights and accountability in the Budget Process. London: Overseas Development Institute. https://www.odi.org/sites/odi.org.uk/files/odi-assets/publications-opinion-files/ 2422.pdf.

Ojha, H. O., Cameron, J. and Kumar, C. 2009. Deliberation or symbolic violence? The governance of community forestry in Nepal. Forest Policy and Economics 11 (5-6): 365-374. https://doi.org/10.1016/j.forpol.2008.11.003

Pettit, P. 2003. Deliberative democracy, the discursive dilemma and republican theory. In Debating deliberative democracy, eds. Fishkin, J. and Levine, P., 138-162. Oxford: Blackwell. 
Philippine Statistics Authority. 2016. 2012 Municipal and city level poverty estimates. https://psa.gov.ph/sites/default/files/2012\%20Municipal\%20and\%20City\%20 Level\%20Poverty\%20Estimates\%20Publication\%20\%281\%29.pdf (accessed 11 April, 2020)

Polletta, F. 2008. Just talk: Public deliberation after 9/11. Journal of Public Deliberation 4 (1): Article 2.

Ritzer, G. 2011. Sociological theory. 8th ed. New York: McGraw Hill.

Rogers, C. R. 1959. A theory of therapy, personality, and interpersonal relationships: as developed in the client-centered framework. In Psychology: A study of a science. Formulations of the person and the social context, ed. Koch, S., 184-256. Vol. 3. New York: McGraw Hill. 1995. A way of being. New York: Houghton Mifflin Company.

Rubin, I. 2014. The politics of public budgeting: Getting and spending, borrowing and balancing. 7th ed. Thousand Oaks, CA: SAGE Publications, Inc.

Rutsaert, P. et al. 2015. Beyond information seeking: Consumers' online deliberation about the risks and benefits of red meat. Food Quality and Preference 39: 191-201. https://doi.org/10.1016/j.foodqual.2014.07.011

Saldaña, J. 2013. The coding manual for qualitative research. Los Angeles, CA: SAGE Publications, Inc.

Schneiderhan, E. and Khan, S. 2008. Reasons and inclusion: The foundation of deliberation. Sociological Theory 26 (1): 1-24. https://doi.org/10.1111/j.1467 $-9558.2008 .00316 . x$

Scudder, M. F. 2016. Beyond empathy: Strategies and ideals of democratic deliberation. Polity 48 (4): 504-522. https://doi.org/10.1057/s41279-016-0001-9

Stanford, K. A. 1992. State budget deliberations: Do legislators have a strategy? Public Administration Review 52 (1): 16-26. https://doi.org/10.2307/976542

Steenbergen, M. R. et al. 2003. Measuring political deliberation: A discourse quality index. Comparative European Politics 1: 21-48. https://doi.org/10.1057/palgrave. cep. 6110002

Stie, E. 2008. Assessing democratic legitimacy from a deliberative perspective. ARENA working paper no. 6, February. Centre for European Studies, University of Oslo, Norway. https://www.sv.uio.no/arena/english/research/publications/arena-working -papers/2001-2010/2008/wp08_06.pdf.

Tracy, K. 1995. Action-implicative discourse analysis. Journal of Language and Social Psychology 14 (1-2): 195-215. https://doi.org/10.1177/0261927X95141011 2005. Reconstructing communicative practices: Action-implicative discourse analysis. In Handbook of language and social interaction, eds. Fitch, K. L. and Sanders, R. E., 301-319. Mahwah, NJ: Lawrence Erlbaum.

Tracy, K. and Hughes, J. M. F. 2014. Democracy-appealing partisanship: A situated ideal of citizenship. Journal of Applied Communication Research 42 (3): 307-324. https://doi.org/10.1080/00909882.2014.911940

Van de Ven, L. G. et al. 2017. Recognizing decision needs: First step for collaborative deliberation in dementia care networks. Patient Education and Counseling 100 (7): 1329-1327. https://doi.org/10.1016/j.pec.2017.01.024 
Venkatesh, R. and Blaskovich, J. 2012. The mediating effect of psychological capital on the budget participation-job performance relationship. Journal of Management Accounting Research 24 (1): 159-175. https://doi.org/10.2308/jmar-50202

Walker, A. P. P. 2016. Self-help or public housing? Lessons from co-managed slum upgrading via participatory budget. Habitat International 55: 58-66. https://doi .org/10.1016/j.habitatint.2016.02.005

Walsh, K. C. (2007). Talking about race: Community dialogues and the politics of difference. Chicago: University of Chicago Press.

White, S. K. 1988. The recent work of Jurgen Habermas: Reason, justice, modernity. Cambridge: University of Cambridge Press.

Wooley, J. T. and Gardner, J. 2017. The effect of "sunshine" on policy deliberation: The case of the Federal Open Market Committee. The Social Science Journal 54 (1): 13-29. https://doi.org/10.1016/j.soscij.2016.09.006 